\title{
FDI and inequality in Sub-Saharan Africa: does democracy matter?
}

\author{
Sean Gossel \\ Graduate School of Business, University of Cape Town, Cape Town, South Africa
}

\begin{abstract}
Purpose - This paper investigates whether democracy plays a mediating role in the relationship between foreign direct investment (FDI) and inequality in Sub-Saharan Africa (SSA).

Design/methodology/approach - The empirical analysis is conducted using fixed effects and system GMM (Generalised Method of Moments) on a panel of 38 Sub-Saharan African countries covering the period of 1990-2018.

Findings - The results find that FDI has no direct effect on inequality whereas democracy reduces inequality directly in both the short run and the long run. The sensitivity analyses find that democracy improves equality regardless of the magnitude of FDI, resource endowment or democratic deepening whereas FDI only reduces inequality once a moderate level of democracy has been achieved.

Social implications - The results discussed above thus have four policy implications. First, these results show that although democracy has inequality reducing benefits, SSA is unlikely to significantly reduce inequality unless the region purposefully diversifies its trade and FDI away from natural resources. Second, the region should continue to expand credit access to reduce inequality and attract FDI. Third, policymakers should undertake reforms that will reduce youth inequality. Lastly, the region should focus on long-run democratic reforms rather than on short-run democratization to improve governance and investor confidence. Originality/value - Although there are existing studies that examine the association between FDI and inequality, FDI and democracy and democracy and inequality, this is the first study to explicitly examine the effect of democracy on the association between FDI and inequality in SSA, and the first study to separately consider the possible varied effects of contemporaneous democratization versus the long-run accumulation of democratic capital. In addition, rather than measure inequality by income alone, this study uses the more appropriate Human Development Index to account for SSA's sociological, education and income disparities.
\end{abstract}

Keywords Democracy, Democratic capital, FDI, Inequality, Sub-Saharan Africa

Paper type Research paper

\section{Introduction}

Over the last quarter century, foreign direct investment (FDI) to Sub-Saharan Africa (SSA) increased from $\$ 1.2 \mathrm{bn}$ in 1990 to $\$ 31 \mathrm{bn}$ in 2018 (World Bank, WDI Data) while the average Polity V democracy index improved from -5 to 3 . Over the same period however, the average Human Development Index (HDI) only improved marginally from 0.40 to 0.53 and thus it appears that greater FDI inflows and deepening democracy have not substantially reduced inequality in SSA. A possible reason for this disappointing effect may be because many SSA countries remain commodity export dependent, which can "crowd out" FDI in non-resource industries (Okafor et al., 2015) and increase the durability of authoritarian regimes (Wantchekon and Jensen, 2000; Asiedu and Lien, 2011). FDI commonly relies on skills-based development, but in resource dependent countries, FDI can increase inequality if it is dominated by resource-seeking FDI (Kaulihowa and Adjasi, 2017), which tends to be exploitative and has negative distributional effects. Hence, the type of FDI (greenfield versus mergers and acquisitions) and the nature of FDI (resource-seeking versus market-seeking) can worsen or mitigate inequality by the extent to which it widens skill and income inequality

(C) Sean Gossel. Published by Emerald Publishing Limited. This article is published under the Creative Commons Attribution (CC BY 4.0) license. Anyone may reproduce, distribute, translate and create derivative works of this article (for both commercial and non-commercial purposes), subject to full attribution to the original publication and authors. The full terms of this license may be seen at http:// creativecommons.org/licences/by/4.0/legalcode

Received 3 March 2021 Revised 12 August 2021 24 November 2021 5 January 2022 19 January 2022 Accepted 24 January 2022 inequality in Sub-Saharan Africa 
(Feenstra and Hanson, 1996; Cornia, 1999; Reuveny and Li, 2003; Herzer and Nunnenkamp, 2011; Herzer et al., 2014).

In addition to the effect of FDI on inequality, Acemoglu and Robinson $(2000,2006)$ posit that the pressure for redistribution can affect democratization depending on the level of intergroup inequality. Democracy attempts to balance the revolutionary redistributive pressure of citizens against the repressive power of the elites, and thus high levels of inequality can make revolution more attractive. Consequently, the threat of revolution can drive democratization to mitigate this threat by committing to future redistribution. Democracy should thus reduce inequality because citizens can vote for parties that represent their working/middle-class interests, which will shift political structures towards greater redistributive and more equitable policies (Lipset, 1959; Lenski, 1966; Gradstein and Milanovic, 2004).

With regard to SSA, Kapstein and Converse (2008) argue that because of the rampant clientelism and patronage networks, ethnolinguistic fragmentation and reliance on commodities, democratization is unlikely to lead to decreasing inequality because it will have little impact on the underlying conditions. Consequently, redistributive pressure is more likely to lead to wealth accumulation among political affiliates seeking to influence economic policy rather than to uplift the poor (Kapstein and Milanovic, 2003; Lederman and Lopez, 2006). This has the effect of eroding governance and social cohesion (Kumar, 2014), which reverses rather than stimulates democratization and worsens inequality (Fosu, 2018). Furthermore, in SSA's resource-dependent countries, the high levels of inter-group inequality arising from concentrated wealth hinders democratization and the possibility of redistribution because the elite are more likely to use repression than to democratize (Boix, 2003; Houle, 2009). Thus, Fayad et al. (2012) reports that resource-dependent SSA countries suffer from a democratic deficit while more diversified countries adhere to the Modernization Hypothesis (Lenski, 1966; Tsai, 1995). Bigsten (2016) and Shimeles and Nabassaga (2018) argue that inequality in SSA is shaped by ethnic fragmentation, colonial history and limited education opportunities, and thus Ibrahim et al. (2020) conclude that structural transformation worsens inequality in the region.

In addition to the effect of democratization on inequality, it has been argued that democratization also shapes the type of FDI that is attracted. On the one hand, it is posited that FDI will be attracted to more democratic countries because democratic institutions can enforce property rights, reduce corruption and provide a stable regulatory and policy environment $(\mathrm{Li}$, 2009). Hence, the liberalization of economic markets through globalization is associated with the adoption of democracy (Bhagwati, 1992; Friedman, 1999; Fukuyama, 1992; Hayek, 1944), which could lessen inequality (Boix, 1998; Reuveny and Li, 2003) via knowledge and technological spillovers (Basu and Guariglia, 2007), the creation of low skilled employment (Deardorff and Stern, 1994) and the weakening of the predatory elite (North and Weingast, 1989; Acemoglu et al., 2005). Critics counter however that FDI may be attracted to less democratic countries that can shield investors from wage, labour and tax demands; offer the opportunity to exploit their market dominance and to negotiate directly with the political elite (Resnick, 2001; Gelbach and Keefer, 2011). Hence, liberalized markets can constrain democracy when free market capitalism empowers multinational corporations to limit the actions of governments, labour markets and civil society, which will widen inequality in turn (Adams et al., 1999; Falk, 1999; Mittelman, 2000).

\subsection{Theoretical foundation}

Acemoglu and Robinson (2008) and Acemoglu et al. (2013) posit that democratic pressure may be more related to the de facto power of the elites than to the redistributive pressure of the poor and middle classes. If the elites are weak and inequality is low, then democratic institutions can take root; whereas if the elites have high de facto power and inequality is high, then there is likely to be low institutional quality (Kotschy and Sunde, 2017) and thus a reversion to political instability and authoritarianism (Houle, 2009; Stiglitz, 2012) [1]. 
Mukherjee and Dutta (2018) however argue that the varied effects of FDI and democracy on inequality can be reconciled by considering the differences between economic and social globalization. Economic globalization, associated with trade and capital flows, impacts governance by exposing the regulatory authorities to international standards, promotes market orientated policies and heightens accountability while social globalization transforms and integrates culture and changes the social conditions of political institutions and governance of the state. Consequently, as countries globalize economically, governance should improve, which in turn, makes the country more attractive as a FDI destination. Thus, these theoretical relationships between FDI, democracy and inequality can be summarized by Figures 1 and 2 .

While there are studies that examine the association between democracy and inequality in SSA, and between FDI and democracy in SSA, there is no study that examines the effect of democracy on the relationship between FDI and inequality in SSA, and no study that considers the effects of contemporaneous democratization versus the long-run accumulation of democratic capital. Hence, this study uses fixed effects and system GMM (Generalised Method of Moments) analysis to determine whether democracy plays a mediating role in the relationship between FDI and inequality in a panel of 38 SSA countries [2] over the period 1990-2018. The remainder of this study is structured as follows. Section 2 briefly reviews the empirical literature. Section 3 discusses the empirical methodology and the data utilized to conduct the analysis. The results are then presented in section 4 , and the study concludes with a discussion of the key findings and policy implications in section 5.

\section{Literature review}

There are two common theories that attempt to explain the effects of FDI on inequality. The first is the technological change hypothesis of Aghion and Howitt $(1998,2009)$ and Aghion and Commander (1999); which posits that inequality increases in the early phases of development as a result of the rapid demand for skilled labour that accompanies the adoption of new technologies and production processes. However, inequality then decreases over time because the supply of skilled labour meets demand as low-skilled workers seek to become more skilled and join the middle classes. The second theory is the North-South hypothesis of Feenstra and Hanson (1997), which argues that FDI worsens inequality because corporations in the more developed countries in the global North will invest in less developed unskilled countries in the global South so as to take advantage of low production costs. FDI thus widens inequality by increasing the demand for skills and higher wages among segments of society in poorer recipient countries in the South.

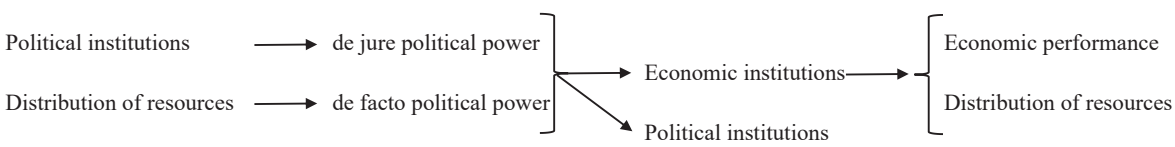

Source(s): Kotschy and Sunde, 2017
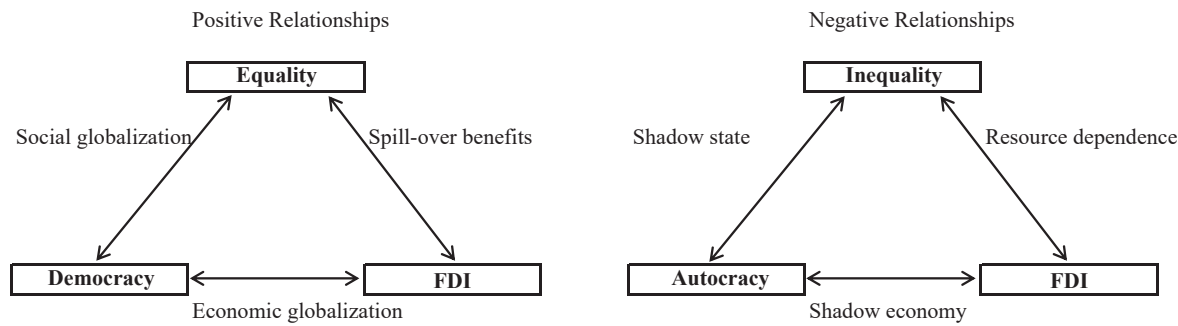

FDI and inequality in Sub-Saharan Africa

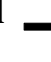


Despite the elegance of the two theories mentioned above, the recent empirical literature that investigates the relationship between FDI and inequality reports mixed results but can generally be classified into four strands. The first includes studies that find that FDI leads to worsening income inequality (Reuveny and Li, 2003; Choi, 2006; Basu and Guariglia, 2007; Herzer and Nunnenkamp, 2011; de Groot, 2014; Alili and Adnett, 2018; Khan et al., 2020). Possible reasons include financial globalization (Bornischer and Chase-Dunn, 1985; Milanovic, 2005; Azis and Shin, 2015; Furceri and Ostry, 2019) and wage inequality between skilled and unskilled labour (Prasad, 2002; Keane and Prasad, 2006; Figini and Gorg, 2011). In contrast, the second strand finds that FDI decreases inequality (Nunnenkamp, 2004; Lehnert et al., 2013) as a result of improved corporate and public sector governance (Hecht et al., 2002), heightened investment (UNDP, 2017) and higher savings (Beer, 2015). The third strand includes studies that find no significant association between FDI and inequality, whether in Deininger and Squire's (1998) cross-country study, Sylwester's (2006) investigation of East Asia, Latin American and Africa or Franco and Gerussi's (2013) study of former central and South-Eastern socialist countries. The last strand includes studies that find mixed results; for instances, Calvo and Hernandez (2006) study of Latin America finds that FDI only reduces inequality if the pre-requisite capital and labour conditions are conducive to spill-over effects, while Bhandari (2007) reports that FDI worsens wage inequality but improves capital inequality and Lee et al. (2020) find that the inequality reducing benefits of FDI weaken as countries become more financially developed.

With regard to the theoretical relationship between democracy and inequality, Modernization Theory posits that inequality increases in the early stages of economic development due to the emergence of a small, modernized, high income class (Tsai, 1995); but over time, as output shifts from primary activities into the industrial sector, declining labour costs and the deepening of political democracy result in a decrease in inequality (Lenski, 1966). Dependency Theory counters however that the reliance on FDI for economic development tends to create an elite pool of labour in international sectors with wages significantly above those in domestic sectors. This hampers efforts to improve broader redistribution (Evans, 1979), and tends to foster capital intensive rather than labour intensive development, which, over time, leads to higher unemployment and inequality (Reuveny and Li, 2003; Milanovic, 2005; Choi, 2006; Herzer and Nunnenkamp, 2011).

Empirical studies on the relationship between inequality and democracy similarly report varied results. Bollen and Jackman (1985), Li et al. (1998), Tavares and Wacziarg (2001), Reuveny and Li (2003), Timmons (2010) and Nikoloski (2015) find no significant evidence that democracy is associated with lower inequality. Muller $(1988,1995)$ however reports that there is an inverse causal association whereby a country that has high inequality at the start of democratization is more likely to revert to authoritarian rule, and thus democracy will only lower inequality if the country begins with low to intermediate levels of inequality. Boix (2003) and Houle (2009) however show that the reverse is not necessarily true because they find that inequality only weakly promotes democratization. Wong (2016) reports that although democracy increases FDI inflows, these inflows worsen income inequality in accordance with Dependency Theory while Islam (2016) reports that the relationship between political freedom and income inequality is a Kutznets curve (Kutznets, 1955). More recently, Trasberg and Bahamonde (2021) show that democracy combined with strong institutions leads to widening inequality through the channels of FDI and the financial sector. Lacroix et al. (2021) similarly argue that FDI is mainly attracted to consolidated democratic liberalizations, and that the higher political risk experienced in the early phases of liberalization offsets any positive inequality reducing benefits of FDI. Wong (2021) posits that these varied results can be explained by the differing effects of democratic contestation and inclusiveness, whereby contestation increases the pressure for redistribution, and therefore potentially decreases inequality; while inclusiveness could widen control by the political elite, thereby decreasing the redistributive pressure and widening inequality. 
Studies that explore the relationship between democracy and FDI in SSA are similarly inconclusive. Onyeiwu and Shrestha (2004) find no significant relationship between FDI and political rights whereas Suliman and Mollick (2009) report that both civil liberties and political rights attract FDI. In contrast, Okafor et al. (2011) finds that as democracy deepens, FDI tends to decrease while Gangi and Abdulrazak (2012) argue that political stability is insignificant for FDI and is more significant for governance. Cleeve (2012) further reports that FDI is attracted by deepening democracy, improved socio-economic conditions and improved investment profiles whereas corruption and political instability are insignificant. Fiodendji (2014) finds a positive association between FDI and institutional quality whereas Aregbeshola (2014) reports that the institutions devoted to fiscal and monetary policies are more important for attracting FDI to SSA. Gossel (2017) further shows that FDI is affected by the long-run accumulation of democratic capital to a greater extent than by short-run democratic reforms or by the components of democracy (civil liberties and political rights) and Kunawotor et al. (2020) find that only the control of corruption and the rule of law reduce inequality while the other common measures of institutional quality are insignificant.

Lastly, in common with the international literature, the results of studies that examine the relationship between FDI and inequality in SSA are also mixed. Gohou and Soumare (2012) report that FDI has a greater welfare enhancing effect in poorer SSA countries than in wealthier countries, and in Central and East Africa than in North, South or West Africa. Batuo and Asongu (2015) find that FDI tends to have a lesser effect on reducing inequality than liberation of the financial system whereas Adams and Klobodu (2017) show that FDI unidirectionally increases income inequality in both the short and the long run. Kaulihowa and Adjasi (2017) report that although FDI is welfare enhancing, the effect varies across the dimensions of welfare, and Kaulihowa and Adjasi (2018) find that FDI does not have a significant effect on inequality in the short run but worsens inequality once the inflows exceed $2.8 \%$ of gross domestic product (GDP) and $\mathrm{Xu}$ et al. (2020) reports that as FDI increases inequality decreases.

\section{Data and methodology}

The empirical estimations make use of one dependent factor, three factors of interest and six control factors.

\subsection{Dependent factor}

There are numerous ways of measuring inequality but many of the common metrics are empirically and theoretically problematic when applied to SSA. Among the most common inequality index is the GINI coefficient, which is based on the Lorenz curve between the cumulative percentage of income held by society against the percentage of the population. The GINI coefficient is bounded between 100, representing perfect income inequality, and 0 , representing perfect income equality. Despite its wide usage, the GINI index is an aggregate measure and is thus unable to differentiate between redistribution from the upper-income to middle-income, and an increase in the lower-income at the expensive of the middle-income class (Deininger and Squire, 1998).

An alternative to the GINI index is the Standardized World Income Inequality Database (SWIID), which is based on the WIID but with imputed data points (Solt, 2016). However, there are concerns about the quality of imputed data points owing to the lack of clarity regarding the imputation process, and in the case of SSA, the dataset is also significantly porous. Furthermore, as shown by Chisadza and Bittencourt (2019), measuring inequality by income alone is problematic in the case of SSA given the regions fraught colonial and postcolonial history. Hence, in accordance with recent studies (Gohou and Soumare, 2012; de

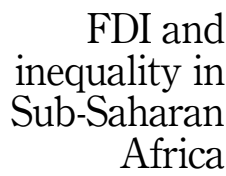

Africa 
Groot, 2014; Yi and Woo, 2015; Kaulihowa and Adjasi, 2017; Khan et al., 2020), this study measures inequality using the HDI (UNDP, 1990; Sen, 1992), which takes account of SSA's significant sociological, education and income disparities rather than focussing only on income inequality as in the GINI or SWIID indices. The HDI ranges between 0 and 1 , where a high HDI score represents a country with a long lifespan, high education level and wealthy GNI. The HDI is therefore interpreted as the opposite of the GINI index since the lower the HDI score, the worse the level of inequality.

\subsection{Independent factors of interest}

In addition to the dependent factor, this study includes three independent factors of interest. The first is the stock of FDI inflows normalized by GDP in current USD $(F D I)$ sourced from the World Bank Development Indicators (WDI). The second is the Polity2 modified version of the Polity V democracy index (Marshall et al., 2020) (Demo), scaled from -10 to 10 with autocracy ranging between -10 and 0 , and democracy between 0 and 10 [3]. This series is then normalized to lie between 0 and 1 . While the Polity $\mathrm{V}$ index is widely used in the literature, it has been argued that the persistence of democracy is more important than contemporaneous democratization (Gerring et al., 2005; Persson and Tabellini, 2009; Jeitschko et al., 2014; Wong, 2016). Thus, the third factor of interest is the democratic capital index (Demo_Cap), measured as the discounted sum of the country's Polity V regime index starting from either 1800 or the year of independence $(\tau)$ and ending in $2018(t)$ :

$$
\text { Democratic Capital }=\frac{\sum_{\tau=1800}^{t=2018} \delta^{\tau} f_{1, t-\tau}}{D}
$$

where $f_{1, t-\tau}$ is the regime index ( 1 if democracy or 0 otherwise), in country $i$ during period $t-\tau, \delta$ is a discount factor that is set to 0.94 and $D=\sum_{\tau}^{t} \delta^{\tau}$ is used for normalization. The democratic capital indices derived from equation (1) thus ranges between 0 (no democratic capital) and 1 (high democratic capital). Hence, the Polity V index captures short-run contemporaneous democratization (Demo) while the democratic capital index accounts for the long-run accumulation of democratic capital (Demo_Cap).

\subsection{Control factors}

In addition to the dependent factor and three factors of interest, the analysis also includes six control factors. The data for the control factors was obtained from the World Bank's World Development Indicators. The first control factor is GDP growth $(G D P G)$ measured as the percentage change in GDP. Economic growth is commonly associated with high FDI inflows (World Bank, 1997) and therefore potentially affects inequality (Basu and Guariglia, 2007). The second control factor is trade as a percentage of GDP (Trade), which is included as a measure of trade openness. Higher trade openness should lead to increased competitiveness and reduce the price of basic goods while also increasing labour productivity through increased competition, thus resulting in rising wages and decreased inequality (Birdsall, 1998). The third control factor is gross fixed capital formation as a percentage of $\mathrm{GDP}(G F C F)$, which consists of expenditure on fixed assets and net changes in inventories. High fixed capital investment is expected to be associated with greater FDI inflows (World Bank, 1993) and declining inequality (Lee, 2005).

The fourth control factor is inflation $(I n f)$ measured by the annual change in the GDP deflator. Inflation is included as a proxy for policy stability. Low inflation may attract FDI (Mishkin, 2008) and stimulate credit extension, which may narrow inequality (IMF, 1998). However, higher inflation may also stimulate rising interest rates, which will be attractive to equity based FDI, but will limit credit extension and heighten debt distress. Hence, high inflation may attract FDI but 
may also widen inequality, especially if there are limited FDI spill-over effects. The fifth control factor is domestic credit extension to the private sector as a percentage of GDP (Credit), which is used as a proxy for financial development. The association between credit and inequality can be positive or negative depending on the level of financial sector depth (Kai and Hamori, 2009), financial development (Batuo et al., 2010; Asongu, 2013) or education level (Tchamyou, 2018; Asongu et al., 2020). The final control factor is population age structure as measured by the logarithm of the proportion of the population under 14 (Pop_U14). A high proportion of youth population can increase or decrease inequality. On the one hand, high population growth can exacerbate inequality by increasing the proportion of the young population in low income groups (Bollen and Jackman, 1985), thus worsening intergenerational inequality (Muller, 1988). However, if a significant proportion of the youth population have access to education and entrylevel employment, then inequality will decline as household incomes and savings improve (Hassan et al., 2011; IMF, 2015).

This study examines the effects of democracy on the relationship between FDI and inequality in 38 SSA countries over the period 1990-2018. In accordance with the relevant literature (Xu et al., 2020; Khan et al., 2020; Kunawotor et al., 2020), the empirical estimations are conducted using fixed effects with robust standard errors, as well as two-step system GMM (Arellano and Bover, 1995; Blundel and Bond, 1998, 2000) including the xtabond2 function of Roodman (2009). The advantages of the system GMM technique are that it is applicable when the cross-sectional units (38) are higher than the time series (28), accounts for cross-country differences, controls for unobserved heterogeneity by taking account of time invariant omitted variables and uses internal instruments to account for reverse causality and endogeneity of the explanatory factors. In addition, two-step system GMM has the added advantages over difference GMM (Arellano and Bond, 1991) of assuming homoscedastic residuals in the first step before correcting for heteroscedasticity thereafter, and is more appropriate for unbalanced panels (Roodman, 2009).

The fixed effects model used to conduct the analysis can be represented by equation (2) while the GMM model is represented by equation (3):

$$
\begin{gathered}
Y_{i, t}=\alpha_{0}+\beta D_{i, t}+\delta X_{i, t}+\mu_{i}+\mu_{t}+\varepsilon_{i, t} \\
Y_{i, t}=Y_{i, t-1}+\beta D_{i, t}+\delta X_{i, t}+\varepsilon_{i, t}
\end{gathered}
$$

where $Y_{i, t}$ denotes inequality for country $i$ at time $t ; D_{i}$ represents the three factors of interest comprising net FDI inflows as a percentage of GDP, and the two democracy factors contemporaneous democracy (Demo) and the accumulation of democratic capital (Demo_Cap); $X_{i}$ is a vector of six macroeconomic control factors comprising economic growth $(G D P G)$, trade openness (Trade), credit extension (Credit), inflation (Inf), fixed investment $(G F C F)$ and youth population (Pop_U14); $\mu_{i}$ is the time-invariant country effect; $\mu_{t}$ is the common time effect and $\varepsilon_{i, t}$ is the error term. In addition to the analysis using equations (2) and (3), the estimations also include two interaction terms (FDI*Demo and FDI*Demo_Cap) to determine whether FDI's association with inequality is more closely associated with contemporaneous democracy or the accumulation of democratic capital.

The empirical estimations make use of the full sample and three sensitivity analyses. The first takes account of the non-homogeneity of FDI inflows to SSA (Okafor et al., 2015) by excluding the six countries where the average of FDI inflows in USD exceeds $5 \%$ of total inflows over the sample period [4]. The second then accounts for SSA's high reliance on commodity exports (Jensen and Wantchekon, 2004; Asiedu and Lien, 2011) by excluding the nine SSA countries where the average of commodity exports or oil rents over the sample period exceeds $25 \%$ of merchandise exports or GDP respectively (IMF, 2012) [5]. The third uses a sub-sample to assess whether the level of democratization has an effect on the associations by excluding the 16 countries [6] where the average normalized Polity V score is below 0.5.
FDI and inequality in Sub-Saharan Africa 


\section{Results}

This section discusses the results of the fixed effects and system GMM analyses of the relationship between democracy, FDI and inequality in 38 SSA countries over the period of 1990-2018. The discussion commences with the results of the full sample, before moving on to the outcomes of the sub-samples. Before applying the fixed effects and GMM analyses, a matrix of correlation coefficients was checked to ensure that there are no significant correlations among the factors. Thereafter, Levin-Lin-Chu (LLC) (2002) common unit root tests and augmented Dickey-Fuller-Fisher chi squared individual unit root tests (Maddala and $\mathrm{Wu}, 1999)$ were applied to ensure that none of the variables are second-difference stationary. The results of the correlations presented in Table 1 show that only contemporaneous democracy (Demo) and democratic capital (Demo_Cap) have a significant correlation coefficient and thus the empirical estimations include these factors separately. The unit root test results summarized in Table 2 show that all the factors are level stationary, except for the HDI, credit extension (Credit) and the population under 14 (Pop_U14) which are first-difference stationary.

The results of the full sample estimations are presented in Table 3 below. With regard to the control factors, economic growth $(G D P G)$, fixed investment $(G F C F)$ and inflation $(I n f)$ significantly decrease inequality while credit extension (Credit) and youth population (Pop_U14) widen inequality. In accordance with the Modernization Hypothesis, positive economic growth and fixed investment lessens inequality levels as a result of improved social mobility, employment and wealth accumulation. The positive coefficients of inflation (Inf) suggest that higher inflation leads to declining inequality, which can arise from reduced real debt service costs (Doepke and Schneider, 2006).

Table 1.

Correlation matrix

\begin{tabular}{lllrrrrrrr}
\hline & HDI & FDI & Demo & Demo_Cap & GDPG & Trade & GFCF & Credit & Pop_U14 \\
\hline HDI & 1 & 0.038 & 0.238 & 0.408 & 0.026 & 0.292 & 0.384 & 0.474 & -0.701 \\
FDI & 0.038 & 1 & 0.086 & 0.094 & 0.064 & 0.293 & 0.275 & -0.050 & -0.007 \\
Demo & 0.238 & 0.086 & 1 & 0.750 & 0.137 & -0.041 & 0.089 & 0.278 & -0.306 \\
Demo_Cap & 0.408 & 0.094 & 0.750 & 1 & 0.072 & 0.042 & 0.095 & 0.400 & -0.438 \\
GDPG & 0.026 & 0.064 & 0.137 & 0.072 & 1 & 0.025 & 0.111 & -0.064 & 0.030 \\
Trade & 0.292 & 0.293 & -0.041 & 0.042 & 0.025 & 1 & 0.374 & -0.012 & -0.297 \\
GFCF & 0.384 & 0.275 & 0.089 & 0.095 & 0.111 & 0.374 & 1 & 0.021 & -0.158 \\
Credit & 0.474 & -0.050 & 0.278 & 0.400 & -0.064 & -0.012 & 0.021 & 1 & -1 \\
Pop_U14 & -0.701 & -0.007 & -0.306 & -0.438 & 0.030 & -0.297 & -0.158 & -0.611 & 1.000 \\
\hline
\end{tabular}

Table 2.

Unit root test results

\begin{tabular}{|c|c|c|c|c|}
\hline & \multicolumn{2}{|c|}{ LLC } & \multicolumn{2}{|c|}{ ADF-Fisher } \\
\hline & $\mathrm{I}(0)$ & $\mathrm{I}(1)$ & $\mathrm{I}(0)$ & $\mathrm{I}(1)$ \\
\hline HDI & 1.039 & $-7.738^{* * * *}$ & 56.396 & $236.188^{* * * *}$ \\
\hline FDI & $-8.059 * * *$ & $-34.828 * * *$ & $228.881^{* * * *}$ & $886.104^{* * *}$ \\
\hline Demo & $-20.810^{* * * *}$ & $-40.877^{* * * *}$ & $464.809 * * *$ & $490.101 * * *$ \\
\hline Demo_Cap & -3.140 **** & $-3.194 * * *$ & 44.406 & $91.183 * * *$ \\
\hline GDPG & $-19.309 * * *$ & $-31.785^{* * * *}$ & $486.720 * * * *$ & $839.268 * * *$ \\
\hline Trade & $-3.869 * * *$ & $-21.699 * * *$ & $139.971^{* * *}$ & $563.441^{* * *}$ \\
\hline GFCF & $-3.939 * * *$ & -20.868 **** & $130.569 * * *$ & $582.552 * * *$ \\
\hline Credit & 0.166 & $-19.123^{* * *}$ & 81.425 & $440.991 * * *$ \\
\hline Pop_U14 & 0.279 & $-2.006^{* *}$ & $107.930 * * *$ & $138.535^{* * *}$ \\
\hline
\end{tabular}

Note(s): Automatic lag selection based on SIC. *** and ** represent significance at the 1 and $5 \%$ level respectively 


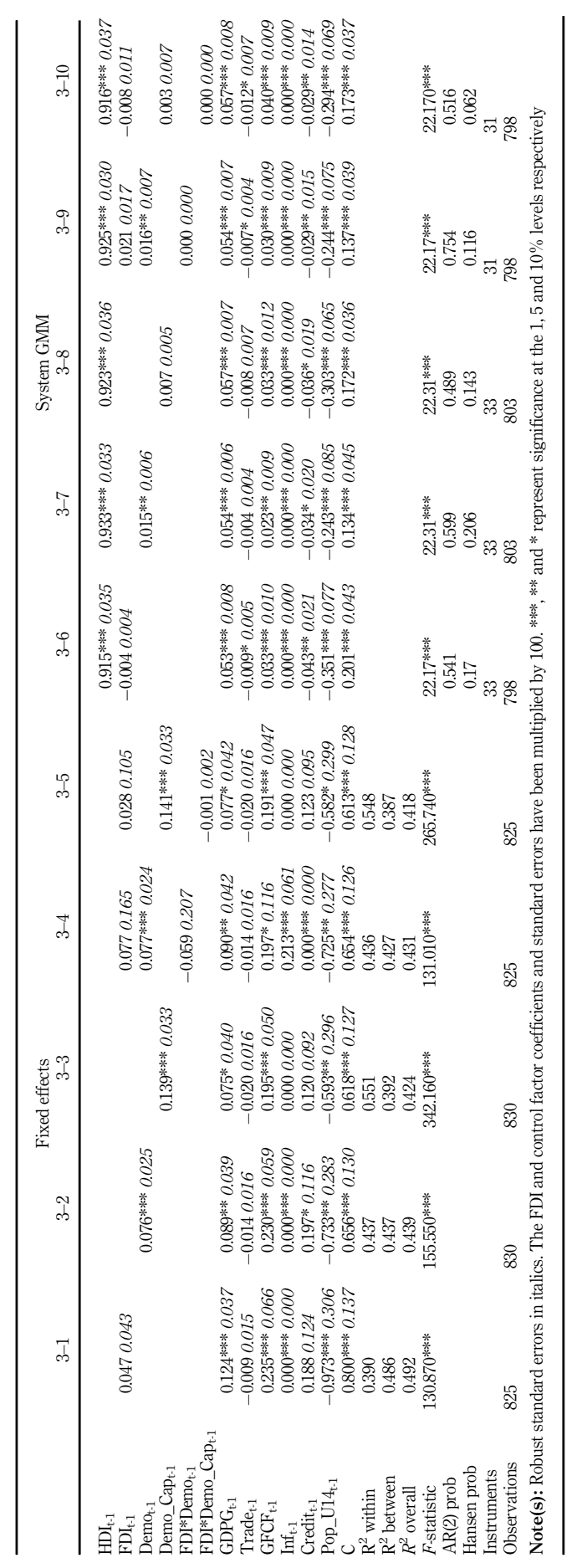

FDI and inequality in Sub-Saharan Africa

Table 3. Full sample results 
The significant and negative GMM coefficients of credit reflects the region's poor financial access (Demirguc-Kunt and Klapper, 2012; Peer, 2013), unsophisticated financial systems (Beck et al., 2004, 2007), limited financial depth (Kai and Hamori, 2009), inefficiency (Asongu, 2013) and limited digital access (Mose and Thomi, 2021), which widens income and gender inequality (Fuentes-Nieva and Galasso, 2014; Aslan et al., 2017). The significant and negative coefficients of youth population (Pop_U14) indicate that a youthful population widens inequality, which accords with the literature (Rougoor and Charles, 2014, 2015). Furthermore, this result implies that the inequality reducing benefits associated with FDI and democracy do not reduce inequality among SSA's youth, which is further supported by the insignificant interaction coefficients (models 3-4 and 3-5) and the significant FDI and democracy coefficients (models 3-1, 3-2, 3-4). Lastly, the insignificant trade openness (Trade) coefficients in most of the estimations possibly reflects SSA's poor diversification status (Gui-Diby and Renard, 2015) and low-skilled commodity-based, rather than upskilled manufacturing-based, labour intensity (IMF, 2019), which limit the inequality reducing benefits associated with trade-led social mobility (Le et al., 2020).

With regard to FDI, the insignificant coefficients (3-1, 3-4, 3-5 and 3-6, 3-9, 3-10) imply that FDI has no effect on inequality in SSA. This result differs from the SSA studies that generally find a positive effect (Gohou and Soumare, 2012; Kaulihowa and Adjasi, 2017; Xu et al., 2020) or negative effect (Anyanwu, 2016; Adams and Klobodu, 2017; Kaulihowa and Adjasi, 2018) but this disparity may be because these studies measure inequality by income inequality only. The insignificance of FDI compared to the negative coefficients of youth population suggests that while improved education levels among the youth should increase FDI levels (Oketch, 2006; Gyimah-Brempong et al., 2006; Suliman and Mollick, 2009) and decrease inequality from knowledge spill-overs (Perri and Peruffo, 2016), this apparently does not apply to SSA. Possible reasons for this disparity are because much of the profits earned from multinational corporations in SSA are repatriated rather than being invested domestically and the capital intensive processes only creates a small skilled labour pool, thus negating labour and knowledge spill-overs in the entry-level labour markets (Baran, 1973; Jenkins, 1996; Lall, 1974; Nafziger, 1997; Odusola et al., 2018).

In the case of democracy, contemporaneous democratization (Demo) in both the fixed effects and GMM models are significant and positive (3-2, 3-4, 3-7, 3-9) whereas the accumulation of democratic capital (Demo_Cap) coefficients are only significant in the fixed effects estimations (3-3, 3-5). Although this indicates that democracy reduces inequality in both the short run and the long run, the larger coefficients of democratic capital compared to those of contemporaneous democracy suggests that the inequality reducing benefits tend to accumulate in the long run. This may be because as democracy becomes entrenched, there is an associated erosion of patronage networks and ethnolinguistic fragmentation (Cheeseman, 2015), and strengthening of the rule of law and limitation of arbitrary government intervention (Globerman and Shapiro, 2002, 2003). This in turn leads to greater political competition, more efficient provision of public goods and services, less corruption, better education levels and higher redistributive policies (Kapstein and Converse, 2008). Hence, in accordance with Gossel (2018) and Kunawotor et al. (2020), these results suggest that it is not necessarily the electoral system of democracy that leads to a reduction in inequality, but rather the long run accompanying institutional reforms.

Lastly, the insignificance of the interaction coefficients (3-4, 3-5, 3-9 and 3-10) indicates that democracy does not play a mediating role in attracting inequality reducing FDI to SSA. This may be because democratization improves the prospects and living standards of the population whereas foreign investors can negotiate with the political elite directly regardless of the improvements in democratic institutions and investor protection legislation (Gehlbach and Keefer, 2011; Resnick, 2001), or because SSA's level of social globalization is still insufficient to facilitate the benefits of economic globalization and governance (Mukherjee and Dutta, 2018). 
Having examined the full sample, the discussion next turns to the results of the subsamples. The estimations that exclude the six countries where the average of FDI inflows in USD exceeds $5 \%$ of total inflows are presented in Table 4 . While most of the control factor results in Table 4 are similar to the full-sample results in Table 3, the noticeable changes are inflation and credit extension, which become insignificant in the GMM estimations. This is possibly because countries use FDI to stimulate financial sector development (Henry, 2000; Desai et al., 2006; Amoh et al., 2019), and thus the secondary FDI recipient countries may lack the financial depth and sophistication required to mitigate inequality.

With regard to FDI and democracy, the results presented in Table 4 are similar to those in Table 3, and thus suggests that the magnitude of FDI flows to SSA countries does not affect the associations presented in the full sample results. This may be because the amount of FDI to the secondary FDI SSA countries has not yet reached a level sufficient to affect labour markets (Mirza et al., 2003) or to produce spill-over effects (Lesher and Miroudot, 2008).

The results of excluding the nine SSA countries where the average commodity exports or oil rents exceeds $25 \%$ of merchandise exports or GDP respectively are presented in Table 5. In contrast to the full sample results of Table 3 , the control factor results in Table 5 are all less significant, particularly economic growth and fixed investment, which reflects SSA's reliance on natural resource exports (Wantchekon and Jensen, 2000; Asiedu and Lien, 2011). This result contrasts with Xu et al. (2020) but suggests that many SSA countries have not yet reached a level of trade diversification (further evidenced by the ongoing insignificance of the trade openness coefficients) where export-led growth has a beneficial effect on inequality.

In the case of the factors of interest, the FDI coefficients remain insignificant and thus the results in Tables 4 and 5 imply that secondary FDI and resource export dependent SSA countries cannot rely on FDI-led growth (de Mello, 1997, 1999) to reduce inequality. Contemporaneous democracy and democratic capital however maintain similar patterns of significance as in Table 3, except that contemporaneous democracy becomes less significant. Hence, these results indicate that, as argued by Wong (2016), democratic deepening more consistently lowers inequality by reforming institutions and reinforcing redistributive policies directly rather than indirectly via FDI's spill-over effects (Borensztein et al., 1998).

The final sensitivity analysis is to assess whether the level of democracy affects the fullsample results. This is accomplished by excluding the 16 countries with average normalized Polity V scores below 0.5 . The results presented in Table 6 show that in contrast to the previous sensitivity analyses, the level of democratization significantly affects the conclusions. With regard to the control factors, economic growth becomes insignificant in the fixed effects estimations, fixed investment and inflation become insignificant in the GMM estimations, and credit and youth population become insignificant in both the fixed effects and GMM estimations. Hence, these results suggest that, similar to the diversified SSA country results in Table 5, macroeconomic and financial development in more democratic SSA countries have not translated into reduced inequality. In addition, the ongoing insignificance of trade openness indicates that despite the inequality reducing promise of export-led growth (Pazim, 2009; Yee-Ee, 2016), trade in SSA does not significantly reduce inequality in more democratic SSA countries. A possible reason is that SSA's persistent patronage and incumbency (Bates et al., 2012; Diamond, 2015), corruption (Kapstein and Converse, 2008) and patrimonial and clientelist networks (Timamy, 2005; Keefer, 2007; Efobi, 2015) means that the benefits associated with globalization are more likely to accrue to the political elite than reduce inequality (Justesen and Bjornskov, 2014).

With regard to the factors of interest, the sign and significance of the democracy coefficients are relatively consistent with Table 3 , suggesting that democracy consistently improves equality regardless of the magnitude of FDI, resource endowment or democratic deepening. However, FDI becomes positive and significant in the GMM estimation (6-6), which indicates that FDI only reduces inequality once SSA countries have achieved a

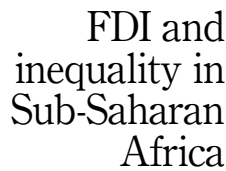


IJOEM

Table 4.

Excluding main FDI recipient countries sub-sample results

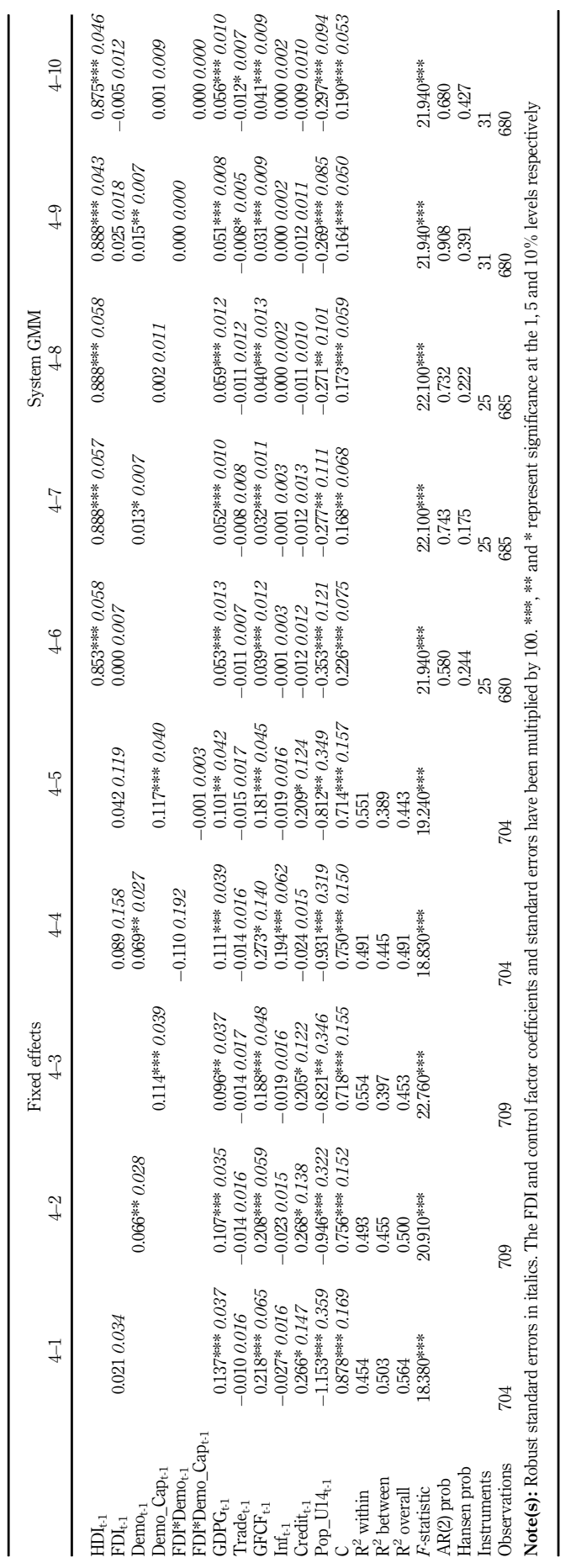




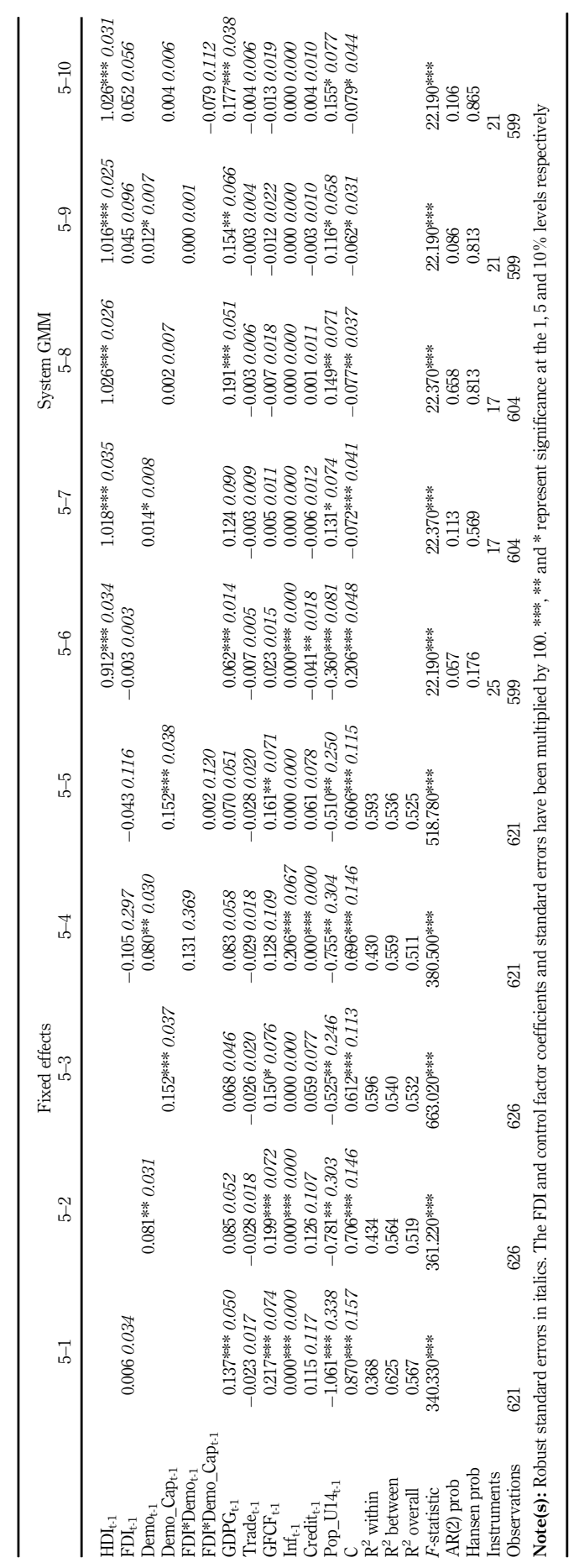

FDI and inequality in Sub-Saharan Africa

Table 5. Excluding resourcedependent countries sub-sample results 
IJOEM

Table 6.

High democracy subsample results

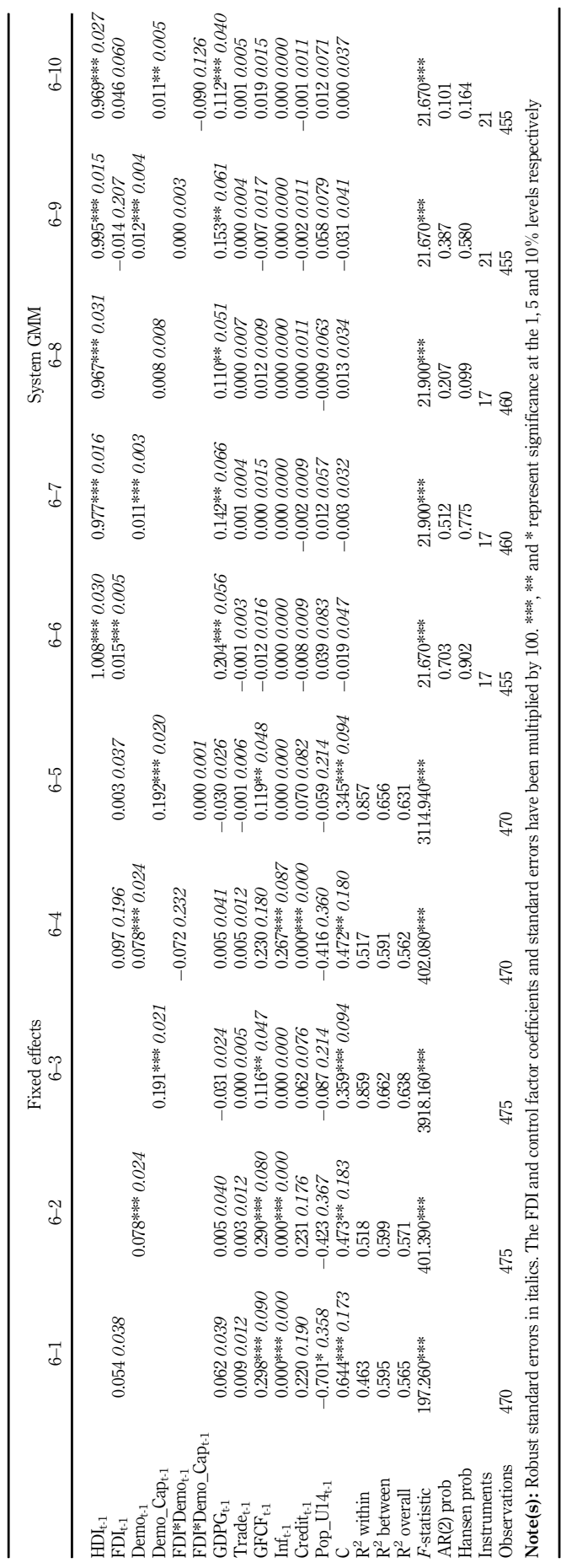


moderate level of democracy, in accordance with Kapstein and Converse (2008). However, the insignificance of the interaction terms $(6-4,6-5,6-9,6-10)$ indicates that democracy does not act as a mediating factor in the relationship between FDI and inequality in more democratic SSA countries, possibly because more democratic SSA countries have already crossed the threshold of rule of law and control of corruption (Kunawotor et al., 2020).
FDI and inequality in Sub-Saharan Africa

\section{Conclusion}

This study used fixed effects and system GMM analysis to examine whether democracy plays a mediating role in the relationship between FDI and inequality in a panel of 38 SSA countries over the period 1990-2018. The full sample results show that FDI has no effect on inequality in SSA whereas democracy reduces inequality in both the short run and the long run. The sensitivity analyses further show that democracy improves equality regardless of the magnitude of FDI, resource endowment or democratic deepening. Lastly, analysis of the more democratic SSA countries reveals that FDI only reduces inequality once a moderate level of democracy has been achieved.

\subsection{Policy implications}

The results discussed above thus have four policy implications. First, these results show that although democracy has inequality reducing benefits, SSA is unlikely to significantly reduce inequality unless the region purposefully diversifies its trade and FDI away from natural resources. Second, the region should continue to expand credit access to reduce inequality and attract FDI. Third, policymakers should undertake reforms that will reduce youth inequality. Lastly, the region should focus on long-run democratic reforms rather than on short-run democratization to improve governance and investor confidence.

\section{Notes}

1. Piketty (2014) and Kotschy and Sunde (2017) however empirically find that high levels of inequality tend to erode democratic institutions rather than stimulate democratization while Savoia et al. (2009) reports that inequality leads to inefficient and exploitative institutions.

2. The countries are listed in Appendix.

3. Polity 2 adjusts the standardized authority codes $(-66,-77,-88)$ into conventional scores.

4. The six countries are the Democratic Republic of Congo, Ethiopia, Ghana, Mozambique, Nigeria and South Africa.

5. The countries are Angola, Central African Republic, Congo, Gabon, Guinea, Mozambique, Niger, Rwanda and Zambia.

6. The countries are indicated in Appendix.

\section{References}

Acemoglu, D. and Robinson, J.A. (2000), "Why did the west extend the franchise? Democracy, inequality, and growth in historical perspective", The Quarterly Journal of Economics, Vol. 115 No. 4, pp. 1167-1199.

Acemoglu, D. and Robinson, J.A. (2006), Economic Origins of Dictatorship and Democracy, Cambridge University Press, New York, NY.

Acemoglu, D. and Robinson, J.A. (2008), "Persistence of power, elites and institutions", American Economic Review, Vol. 98 No. 1, pp. 267-293. 
Acemoglu, D., Johnson, S. and Robinson, J.A. (2005), "Institutions as the fundamental cause of longrun growth", in Aghion, P. and Durlauf, S. (Eds.), Handbook of Economic Growth, Vol. 1A, North Holland, Amsterdam, Netherlands.

Acemoglu, D., Robinson, J.A. and Torvik, R. (2013), "Why do voters dismantle checks and balances?”, Review of Economic Studies, Vol. 80 No. 3, pp. 845-875.

Adams, S. and Klobodu, E.K.M. (2017), "Capital flows and the distribution of income in Sub-Saharan Africa”, Economic Analysis and Policy, Vol. 55, pp. 169-178.

Adams, F., Gupta, S.D. and Mengisteab, K. (1999), "Globalization and the dilemmas of the state", in Adams, F., Gupta, S.D. and Mengisteab, K. (Eds), Globalization and the Developing World: An Introduction, Macmillan, London, UK.

Aghion, P. and Commander, S. (1999), "On the dynamics of inequality in the transition", Economics of Transition, Vol. 7 No. 2, pp. 275-298.

Aghion, P. and Howitt, P. (1998), Endogenous Growth Theory, The MIT Press, Cambridge, MA and London.

Aghion, P. and Howitt, P. (2009), The Economics of Growth, MIT Press, Cambridge.

Alili, M.Z. and Adnett, N. (2018), "Did FDI increase wage inequality in transition economies?", International Journal of Social Economics, Vol. 45 No. 9, pp. 1283-1304.

Amoh, J.K., Abdallah, A.M. and Fosu, R.A. (2019), "Does foreign direct investment cause financial sector development - evidence from an emerging economy", Review of Business and Economic Studies, Vol. 12 No. 1, pp. 33-55.

Anyanwu, J.C. (2016), "Empirical analysis of the Main drivers of income inequality in Southern Africa”, African Development Review, Vol. 17 No. 2, pp. 337-364.

Aregbeshola, A.R. (2014), "Foreign direct investment and institutional adequacy: new Granger causality evidence from African countries", South African Journal of Economic and Management Sciences, Vol. 17 No. 5, pp. 557-568.

Arellano, M. and Bond, S. (1991), "Some tests of specification for panel data: Monte Carlo evidence and an application to employment equations", Review of Economic Studies, Vol. 58 No. 2, pp. 277-297.

Arellano, M. and Bover, O. (1995), "Another look at the instrumental variables estimation of errorcomponents models", Journal of Econometrics, Vol. 68, pp. 29-51.

Asiedu, E. and Lien, D. (2011), "Democracy, foreign direct investment and natural resources", Journal of International Economics, Vol. 84 No. 1, pp. 99-111.

Aslan, G., Deléchat, C., Newiak, M. and Yang, F. (2017), "Inequality in financial inclusion and income inequality", IMF Working Paper WP/17/236, Washington DC.

Asongu, S.A. (2013), "Investment and inequality in Africa. Which financial channels are good for the poor?", African Finance Journal, Vol. 15 No. 2, pp. 44-65.

Asongu, S.A., Nnanna, J. and Acha-anyi, P.N. (2020), "Finance, inequality and inclusive education in Sub-Saharan Africa”, Economic Analysis and Policy, Vol. 67, pp. 115-162.

Azis, I.J. and Shin, H.S. (2015), Capital Flows and Income Distribution," Managing Elevated Risk, Springer, Singapore, pp. 79-99.

Baran, P.A. (1973), The Political Economy of Growth, Penguin, New York, NY.

Basu, P. and Guariglia, A. (2007), "Foreign direct investment, inequality, and growth", Journal of Macroeconomics, Vol. 29 No. 4, pp. 824-839.

Bates, R.H., Fayad, G. and Hoeffler, A. (2012), "The state of democracy in Sub-Saharan Africa", International Area Studies Review, Vol. 15 No. 4, pp. 323-338.

Batuo, M.E. and Asongu, S.A. (2015), "The impact of liberalization policies on income inequality in African countries", Journal of Economic Studies, Vol. 42 No. 1, pp. 68-100.

Batuo, M.E., Guidi, F. and Mlambo, K. (2010), "Financial development and income inequality: evidence from Africa Countries", Paper No. 25658, MPRA. 
Beck, T., Demirguc-Kunt, A. and Levine, R. (2004), "Finance, inequality, and poverty: cross-country evidence”, NBER Working Paper Series 10979.

Beck, T., Demirguc-Kunt, A. and Levine, R. (2007), "Finance, inequality and the poor", Journal of Economic Growth, Vol. 12, pp. 27-49.

Beer, L. (2015), “Income inequality and transnational corporate penetration”, Journal of World-Systems Research, Vol. 8 No. 1, pp. 1-25.

Bhagwati, J.N. (1992), "Democracy and development”, Journal of Democracy, Vol. 3 No. 3, pp. 37-44.

Bhandari, B. (2007), "Effect of inward foreign direct investment on income inequality in transition countries", Journal of Economic Integration, Vol. 22 No. 4, pp. 888-928.

Bigsten, A. (2016), "Determinants of the evolution of inequality in Africa", Journal of African Economies, Vol. 27 No. 1, pp. 1-22.

Birdsall, N. (1998), "Life is unfair: in the inequality World", Foreign Policy, Vol. 111, pp. 76-93.

Blundell, R. and Bond, S. (1998), "Initial conditions and moment restrictions in dynamic panel data models", Journal of Econometrics, Vol. 87 No. 1, pp. 115-143.

Blundell, R. and Bond, S. (2000), "GMM estimation with persistent panel data: an application to production functions", Econometric Reviews, Vol. 19 No. 3, pp. 321-340.

Boix, C. (1998), Political Parties, Growth and Equality, Cambridge University Press, New York, NY.

Boix, C. (2003), "Democracy and redistribution”, in Levi, M. (Ed), Cambridge University Press, New York, NY.

Bollen, K.A. and Jackman, R.W. (1985), "Political democracy and the size distribution of income", American Sociological Review, Vol. 50 No. 4, pp. 438-457.

Borensztein, E., De Gregorio, J. and Lee, J.W. (1998), "How does foreign direct investment affect economic growth?”, Journal of International Economics, Vol. 45, pp. 115-135.

Bornschier, V. and Chase-Dunn, C. (1985), Transnational Corporations and Underdevelopment, Praeger Press, New York, NY.

Calvo, C. and Hernandez, M.A. (2006), Foreign Direct Investment and Poverty in Latin America, Leverhulme Centre for Research on Globalisation and Economic Policy, University of Nottingham, Nottingham.

Cheeseman, N. (2015), Democracy in Africa: Successes, Failures, and the Struggle for Political Reform, Cambridge University Press, Cambridge.

Chisadza, C. and Bittencourt, M. (2019), "Economic development and democracy: the modernization hypothesis in Sub-Saharan Africa", The Social Science Journal, Vol. 56 No. 2, pp. 243-247.

Choi, C. (2006), "Does foreign direct investment affect domestic income inequality?", Applied Economics Letters, Vol. 13 No. 12, pp. 811-814.

Cleeve, E. (2012), "Political and institutional impediments to foreign direct investment inflows to SubSaharan Africa", Thunderbird International Business Review, Vol. 54 No. 4, pp. 469-477.

Cornia, G.A. (1999), "Liberalization, globalization and income distribution", UNU/WIDER Working Paper No. 157, Helsinki, UNU/WIDER.

de Groot, O.J. (2014), "Foreign direct investment and welfare", Production Development Paper No. 196, United Nations, Santiago, Chile.

de Mello, L.R. (1997), "Foreign direct investment in developing countries and growth: a selective survey", Journal of Development Studies, Vol. 34, pp. 1-24.

de Mello, L.R. (1999), "Foreign direct investment-led growth: evidence from time series and panel data”, Oxford Economic Papers, Vol. 51 No. 1, pp. 133-151.

Deardorff, A.V. and Stern, R.M. (1994), The Stopler-Samuelson Theorem: A Golden Jubilee, University of Michigan Press, Ann Arbor, NI.

Deininger, K. and Squire, L. (1998), "New ways of looking at old issues: inequality and growth", Journal of Development Economics, Vol. 57 No. 2, pp. 259-287. inequality in

Sub-Saharan

Africa

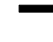


Demirgüç-Kunt, A. and Klapper, L. (2012), "Financial inclusion in Africa", World Bank Policy Research Working Paper 6088.

Desai, M.A., Foley, C.F. and Hines, J.R. (2006), "Capital controls, liberalizations, and foreign direct investment", The Review of Financial Studies, Vol. 19 No. 4, pp. 1433-1464.

Diamond, L.J. (2015), "Facing up to the democratic recession", Journal of Democracy, Vol. 26 No. 1, pp. 141-155.

Doepke, M. and Schneider, M. (2006), "Inflation and the redistribution of nominal wealth", Journal of Political Economy, Vol. 114 No. 6, pp. 1069-1099.

Efobi, U. (2015), "Politicians' attributes and institutional quality in Africa: a focus on corruption", Journal of Economic Issues, Vol. 49 No. 3, pp. 787-813.

Evans, P.B. (1979), Dependent Development: The Alliance of Multinational, State, and Local Capital in Brazil, Princeton University Press, Princeton, NJ.

Falk, R. (1999), Predatory Globalization: A Critique, Polity Press, Cambridge, MA.

Fayad, G., Bates, R.H. and Hoeffler, A. (2012), "Income and democracy: lipset's law inverted”, OxCarre Research Paper 61, Harvard University.

Feenstra, R.C. and Hanson, G.H. (1996), "Globalization, outsourcing and wage inequality", NBER Working Paper No. 5424, Washington DC.

Feenstra, R.C. and Hanson, G.H. (1997), "Foreign direct investment and relative wages: evidence from Mexico's maquiladoras", Journal of International Economics, Vol. 42, pp. 371-393.

Figini, P. and Görg, H. (2011), "Does foreign direct investment affect wage inequality? An empirical investigation", The World Economy, Vol. 34 No. 9, pp. 1455-1475.

Fiodendji, D. (2014), "Do institutions quality affect FDI inflows in Sub Saharan African countries?", SSRN Electronic Journal, Vol. 57414, pp. 0-24.

Fosu, A.K. (2018), "Economic structure, growth, and evolution of inequality and poverty in Africa: an overview", Journal of African Economies, Vol. 27 No. 1, pp. 1-9.

Franco, C. and Gerussi, E. (2013), "Trade, foreign direct investments (FDI) and income inequality: empirical evidence from transition countries", Journal of International Trade and Economic Development, Vol. 22 No. 8, pp. 1131-1160.

Friedman, T.L. (1999), The Lexus and the Olive Tree: Understanding Globalization, Farrar, Straus and Giroux, LLC, New York, NY.

Fuentes-Nieva, R. and Galasso, V.N. (2014), "Working for the few: political capture and economic inequality", MPRA Paper No.54984.

Fukuyama, F. (1992), The End of History and the Last Man, Free Press, New York, NY.

Furceri, D. and Ostry, J.D. (2019), "Robust determinants of income inequality", Oxford Review of Economic Policy, Vol. 35 No. 3, pp. 490-517.

Gangi, Y.A. and Abdulrazak, R.S. (2012), "The impact of governance on FDI flows to african countries", World Journal of Entrepreneurship, Management and Sustainable Development, Vol. 8 Nos 2/3, pp. 162-169.

Gehlbach, S. and Keefer, P. (2011), "Investment without democracy: ruling-party institutionalization and credible commitment in autocracies", Journal of Comparative Economics, Vol. 39 No. 2, pp. 123-139.

Gerring, J., Bond, P., Barndt, W.T. and Moreno, C. (2005), "Democracy and economic growth: a historical perspective", World Politics, Vol. 57, pp. 323-336.

Globerman, S. and Shapiro, D. (2002), "Global foreign direct investment flows: the role of governance infrastructure”, World Development, Vol. 30, pp. 1899-1919.

Globerman, S. and Shapiro, D. (2003), "Governance infrastructure and US foreign direct investment", Journal of International Business Studies, Vol. 4 No. 1, pp. 19-39. 
Gohou, G. and Soumare, I. (2012), "Does foreign direct investment reduce poverty in Africa and are there regional differences?", World Development, Vol. 40 No. 1, pp. 75-95.

Gossel, S.J. (2017), "Democratic capital, democratic rights and FDI in Sub-Saharan Africa”, Journal of International Development, Vol. 29 No. 8, pp. 1033-1061.

Gossel, S.J. (2018), "Corruption, democracy, and FDI in Sub-Saharan Africa", Journal of Policy Modeling, Vol. 40, pp. 647-662.

Gradstein, M. and Milanovic, B. (2004), "Does libertè = egalité? A survey of the empirical links between democracy and inequality with some evidence on the transition economies", Journal of Economic Surveys, Vol. 18 No. 4, pp. 515-537.

Gui-Diby, S.L. and Renard, M.F. (2015), "Foreign direct investment inflows and the industrialization of African countries", World Development, Vol. 74, pp. 43-57.

Gyimah-Brempong, K., Paddison, O. and Mitiku, W. (2006), "Higher education and economic growth of Africa”, Journal of Development Studies, Vol. 42, pp. 509-529.

Hassan, M.K., Sanchez, B. and Yu, J. (2011), "Financial development and economic growth: new evidence from panel data", Quarterly Review of Economics and Finance, Vol. 51, pp. 88-104.

Hayek, F.A. (1944), "Scientism and the study of society. Part III", Economica, Vol. 11 No. 41, pp. 27-39.

Hecht, Y., Razin, A. and Shinar, N.G. (2002), "Interactions between capital inflows and domestic investment: international panel data", Paper Presented at Pinhas Sapir Center Conference on FDI, Tel-Aviv University.

Henry, P.B. (2000), "Do stock market liberalizations cause investment booms?", Journal of Financial Economics, Vol. 50 Nos 1-2, pp. 301-334.

Herzer, D. and Nunnenkamp, P. (2011), "FDI and income inequality: evidence from Europe", Kiel Working Paper No.1675, available at: https://www.econstor.eu/handle/10419/45887, p. 1675.

Herzer, D., Hühne, P. and Nunnenkamp, P. (2014), "FDI and income inequality-evidence from Latin American economies", Review of Development Economics, Vol. 18 No. 4, pp. 778-793.

Houle, C. (2009), "Inequality and democracy: why inequality harms consolidation but does not affect democratization”, World Politics, Vol. 61 No. 4, pp. 589-622.

Ibrahim, M., Vo, X.V. and Aluko, O.A. (2020), "Structural transformation-income inequality nexus in Africa: does the developer's dilemma hold?", Journal of Public Affairs, Vol. 21 No. 2, pp. 1-7.

IMF (1998), "Income inequality: does inflation matter?", Working Paper WP/98/7 Washington DC.

IMF (2012), "Regional economic outlook: Sub-Saharan Africa”, Chapter 3, Washington DC.

IMF (2015), "World economic and financial surveys - regional economic outlook: Sub-Saharan Africa - navigating headwinds", available at: www.imf.org/external/pubs/ft/reo/2015/afr/eng/ pdf/sreo0415.pdf.

IMF (2019), "The African continental free trade agreement: welfare gains estimates from a general equilibrium model", Working Paper WP/19/124, Washington DC.

Islam, M.N. (2016), "Does democracy reduce income inequality?”, Empirical Economics, Vol. 51 No. 4, pp. 1299-1318.

Jeitschko, T.D., Linz, S.J., Noguera, J. and Semykina, A. (2014), "Economic security and democratic capital: why do some democracies survive and others fail?", Journal of Behavioral and Experimental Economics, Vol. 50, pp. 13-28.

Jenkins, R. (1996), "Theoretical perspectives on the transnational corporation", in Goddard, C.R., Passe-Smith, J.T. and Conklin, J.G. (Eds), International Political Economy: State-Market Relations in the Changing Global Order, Lynne Rienner, Boulder, CO, pp. 439-459.

Jensen, N. and Wantchekon, L. (2004), "Resource wealth and political regimes in Africa", Comparative Political Studies, Vol. 37, pp. 816-841.

Justesen, M.K. and Bjornskov, C. (2014), "Exploiting the poor: bureaucratic corruption and poverty in Africa”, World Development, Vol. 58, pp. 106-115. inequality in

Sub-Saharan

Africa

\section{$\longrightarrow$}

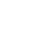


Kai, H. and Hamori, S. (2009), "Globalization, financial depth, and inequality in Sub-Saharan Africa", Economics Bulletin, Vol. 29 No. 3, pp. 2025-2037.

Kapstein, E.B. and Converse, N. (2008), The Fate of Young Democracies, Cambridge University Press, New York.

Kapstein, E.B. and Milanovic, B. (2003), Income and Influence: Social Policy in Emerging Market Economies, Upjohn Institute, Kalamazoo, MI.

Kaulihowa, T. and Adjasi, C. (2017), "FDI and welfare dynamics in Africa", Thunderbird International Business Review, Vol. 60 No. 3, pp. 313-328.

Kaulihowa, T. and Adjasi, C. (2018), "FDI and income inequality in Africa", Oxford Development Studies, Vol. 46 No. 2, pp. 250-265.

Keane, M. and Prasad, E. (2006), "Changes in the structure of earnings during the polish transition", Journal of Development Economics, Vol. 80 No. 2, pp. 389-427.

Keefer, P. (2007), "The political economy of development", in Boix, C. and Stokes, S.C. (Eds), The Oxford Handbook of Comparative Politics, Oxford University Press, New York.

Khan, I., Nawaz, Z. and Saeed, B.B. (2020), "Does trade openness and FDI reduce inequality? Evidence from South Asia”, International Journal of Financial Economics, Vol. 26, pp. 6459-6470.

Kotschy, R. and Sunde, U. (2017), "Democracy, inequality, and institutional quality", European Economic Review, Vol. 91, pp. 209-228.

Kumar, C. (2014), "Africa rising? Inequalities and the essential role of fair taxation", Tax Justice Network Africa, available at: http://www.taxjusticeafrica.net.

Kunawotor, M.E., Bokpin, G.A. and Barnor, C. (2020), "Drivers of income inequality in Africa: does institutional quality matter?", African Development Review, Vol. 32, pp. 718-729.

Kuznets, S. (1955), "Economic growth and income inequality", The American Economic Review, Vol. 45 No. 1 , pp. 1-28.

Lacroix, J., Meon, P.-G. and Sekkat, K. (2021), "Democratic transitions can attract foreign direct investment: effect, trajectories, and the role of political risk", Journal of Comparative Economies, Vol. 49, pp. 340-357.

Lall, S. (1974), "Less-developed countries and private foreign direct investment: a review article", World Development, Vol. 2 Nos 4-5, pp. 43-48.

Le, T.-H.N., Nguyen, C.P., Su, T.D. and Tran-Nam, B. (2020), "The Kuznets curve for export diversification and income inequality: evidence from a global sample", Economic Analysis and Policy, Vol. 65, pp. 21-39.

Lederman, D. and Lopez, R. (2006), "Political institutions, inequality, and agricultural growth: the public expenditure connection", World Bank Policy Research Working Paper No. 3902, Washington DC.

Lee, C.-S. (2005), "Income inequality, democracy, and public sector size", American Sociological Review, Vol. 70 No. 1, pp. 158-181.

Lee, C.C., Lee, C.C. and Cheng, C.Y. (2020), "The impact of FDI on income inequality: evidence from the perspective of financial development", International Journal of Financial Economics, Vol. 27 No. 1, pp. 137-157, doi: 10.1002/ijfe.2143.

Lehnert, K., Benmamoun, M. and Zhao, H. (2013), "FDI inflow and human development: analysis of FDI's impact in host countries' social welfare and infrastructure", Thunderbird International Business Review, Vol. 55 No. 3, pp. 285-298.

Lenski, G. (1966), Power and Privilege: A Theory of Social Stratification, McGraw Hill Education, New York, NY.

Lesher, M. and Miroudot, S. (2008), "FDI spillovers and their interrelationships with trade", OECD Trade Policy Paper No. 80, OECD Publishing, Paris. 
Levin, A., Lin, C. and Chu, C.J. (2002), "Unit root tests in panel data: asymptotic and finite-sample properties", Journal of Econometrics, Vol. 108, pp. 1-24.

Li, Q. (2009), "Democracy, autocracy, and foreign expropriation of foreign direct investment", Comparative Political Studies, Vol. 42 No. 8, pp. 1098-1127.

Li, H., Squire, L. and Zou, H.F. (1998), "Explaining international and intertemporal variations in income inequality", Journal of Economics, Vol. 108 No. 1, pp. 26-43.

Lipset, M. (1959), "Some social requisites of democracy: economic development and political legitimacy”, American Political Science Association, Vol. 53 No. 1, pp. 69-105.

Maddala, G.S. and Wu, S.A. (1999), "Comparative study of unit root tests with panel data and a new simple test", Oxford Bulletin of Economics and Statistics, Vol. 61, pp. 631-652.

Marshall, M.G., Gurr, T.R. and Jaggers, K. (2020), Polity TM V Project Political Regime Characteristics and Transitions, 1800-2018, available at: https://dss.princeton.edu/catalog/resource93.

Milanovic, B. (2005), "Can we discern the effect of globalization on income distribution? Evidence from household surveys", World Bank Economic Review, Vol. 19 No. 1, pp. 21-44.

Mirza, H., Giroud, A., Jalilian, H., Weiss, J., Freeman, N.J. and Than, M. (2003), Regionalization, Foreign Direct Investment and Poverty Reduction: The Case of ASEAN, University of Bradford, Bradford, England.

Mishkin, F. (2008), "Challenges for inflation targeting in emerging market countries", Emerging Markets Finance and Trade, Vol. 44 No. 6, pp. 5-16.

Mittelman, J.H. (2000), The Globalization Syndrome, Princeton University Press, Princeton.

Mose, N. and Thomi, J. (2021), "The determinants of financial inclusion”, Financial Internet Quarterly, Vol. 17 No. 2, pp. 51-58.

Mukherjee, D. and Dutta, N. (2018), "What determines governance across nations: do economic and social globalization play a role?”, Economic Modelling, Vol. 69, pp. 103-113.

Muller, E.N. (1988), "Democracy, economic development, and income inequality", American Sociological Review, Vol. 53 No. 1, pp. 50-68.

Muller, E.N. (1995), "Economic determinants of democracy", American Sociological Review, Vol. 60 No. 6, pp. 966-982.

Nafziger, W. (1997), The Economics of Developing Countries, Prentice-Hall, Englewood Cliffs, NJ.

Nikoloski, Z. (2015), "Democracy and income inequality: revisiting the long- and short-term relationship", Review of Economics and Institutions, Vol. 6 No. 2, pp. 1-24.

North, D. and Weingast, B. (1989), "Constitutions and commitment: the evolution of institutions governing public choice in seventeenth century England", Journal of Economic History, Vol. 49, pp. 803-832.

Nunnenkamp, P. (2004), "To what extent can foreign direct investment help achieve international development goals?", The World Economy, Vol. 27 No. 5, pp. 657-677.

Odusola, A., Mugisha, F., Workie, Y. and Reeves, W. (2018), Income Inequality and Population Growth in Africa, UNDP, New York, available at: https:/www.undp.org/content/dam/rba/docs/Reports/ undp-rba_Income $\% 20$ Inequality $\% 20$ in $\% 20$ SSA_Chapter $\% 209$.pdf.

Okafor, C.E., Ujah, N.U., Elkassabgi, A.Y. and Ajalie, W.U. (2011), "Democracy and FDI inflows: evidence of discordance in Sub-Saharan Africa", International Research Journal of Finance and Economics, Vol. 63, pp. 140-149.

Okafor, G., Piesse, J. and Webster, A. (2015), "The motives for inward FDI into Sub-Saharan African countries", Journal of Policy Modeling, Vol. 37, pp. 875-890.

Oketch, M. (2006), "Determinants of human capital formation and economic growth of African countries”, Economics of Education Review, Vol. 25, pp. 554-564.

Onyeiwu, S. and Shrestha, H. (2004), "Determinants of foreign direct investment in Africa", Journal of Developing Societies, Vol. 20 Nos 1-2, pp. 89-106.
FDI and
inequality in
Sub-Saharan
Africa 
Pazim, K.H. (2009), Panel Data Analysis of Export-Led Growth Hypothesis in BIMP-EAGA Countries, University Library of Munich, Munich.

Peer, S. (2013), “Access to finance: Sub-Saharan Africa”, Working Paper No. 94882, World Bank, Washington DC.

Perri, A. and Peruffo, E. (2016), "Knowledge spillovers from FDI: a critical review from the international business perspective", International Journal of Management Reviews, Vol. 18, pp. 3-27.

Persson, T. and Tabellini, G. (2009), "The nexus of political and economic change", American Economic Journal: Macroeconomics, Vol. 1 No. 2, pp. 88-126.

Piketty, T. (2014), Capital in the 21st Century, Harvard University Press, Cambridge Massachusetts.

Prasad, E. (2002), "Wage inequality in the United Kingdom, 1975-99", IMF Staff Papers, Vol. 49 No. 3, pp. 339-363.

Resnick, A.L. (2001), "Investors, turbulence, and transition: democratic transition and foreign direct investment in nineteen developing countries", International Interactions, Vol. 27, pp. 381-398.

Reuveny, R. and Li, Q. (2003), "Economic openness, democracy and income inequality", Comparative Political Studies, Vol. 36 No. 5, pp. 575-601.

Roodman, D. (2009), "How to do xtabond2: an introduction to difference and system GMM in Stata", Stata Journal, Vol. 9 No. 1, pp. 86-136.

Rougoor, W. and Charles, V.M. (2014), Demography and Growth: Two Forces Leading to Rising Global Income Inequality, SEO Economic Research, Amsterdam.

Rougoor, W. and Charles, V.M. (2015), "Demography, growth and global income inequality", World Development, Vol. 74, pp. 220-232.

Savoia, A., Easaw, J. and McKay, A. (2009), "Inequality, democracy, and institutions: a critical review of recent research", World Development, Vol. 38 No. 2, pp. 142-154.

Sen, A. (1992), Inequality Re-examined, Russell Sage Foundation, New York.

Shimeles, A. and Nabassaga, T. (2018), "Why is inequality high in Africa?", Journal of African Economies, Vol. 27 No. 1, pp. 108-126.

Solt, F. (2016), "The standardized world income inequality Database”, Social Science Quarterly, Vol. 97 No. 5, pp. 1267-1281.

Stiglitz, J. (2012), The Price of Inequality: How Today's Divided Society Endangers Our Future, W. W. Norton, New York.

Suliman, A.H. and Mollick, A.V. (2009), "Human capital development, war and foreign direct investment in Sub-Saharan Africa”, Oxford Development Studies, Vol. 37 No. 1, pp. 47-61.

Sylwester, K. (2006), "Foreign direct investment, growth and income inequality in less developed countries", International Review of Applied Economics, Vol. 19 No. 3, pp. 289-300.

Tavares, J. and Wacziarg, R. (2001), "How democracy affects growth", European Economic Review, Vol. 45, pp. 1341-1378.

Tchamyou, V.S. (2018), "Education, lifelong learning, inequality and financial access: evidence from African countries", Contemporary Social Science, Vol. 15, pp. 1-19.

Timamy, K.M.H. (2005), "African leaders and corruption”, Review of African Political Economy, Vol. 32 Nos 104/105, pp. 383-393.

Timmons, J.F. (2010), "Does democracy reduce economic inequality?”, British Journal of Political Science, Vol. 40 No. 4, pp. 741-757.

Trasberg, M. and Bahamonde, H. (2021), "Inclusive institutions, unequal outcomes: democracy, state capacity, and income inequality”, European Journal of Political Economy, Vol. 70 No. C, pp. 1-21, doi: 10.1016/j.ejpoleco.2021.102048. 
Tsai, P. (1995), "Foreign direct investment and income inequality: further evidence", World Development, Vol. 23 No. 3, pp. 469-483.

UNDP (1990), Human Development Report, UNDP, New York.

UNDP (2017), "Income Inequality trends in Sub-Saharan Africa: Divergence, determinants and consequences", available at: https://www.undp.org/content/dam/rba/docs/Reports/OverviewIncome $\% 20$ inequality $\% 20$ Trends $\% 20$ SSA-EN-web.pdf.

Wantchekon, L. and Jensen, N. (2000), "Resource wealth and political regimes in Africa", African Studies Research Working Paper, Yale University, New Haven, Connecticut.

Wong, M.Y.H. (2016), "Democratic persistence and inequality: the role of foreign direct investments", Studies in Comparative International Development, Vol. 51, pp. 103-123.

Wong, M.Y.H. (2021), "Democracy, hybrid regimes, and inequality: the divergent effects of contestation and inclusiveness", World Development, Vol. 146, pp. 1-11.

World Bank (1993), "Foreign direct investment-benefits beyond insurance", Development Brief, Vol. 14, Washington, DC, Development Economics Vice-Presidency.

World Bank (1997), Private Capital Flows to Developing Countries: The Road to Financial Integration, Oxford University Press, New York.

Xu, C., Han, M., Dossou, T.A.M. and Bekun, F.V. (2020), “Trade openness, FDI, and income inequality: evidence from Sub-Saharan Africa", African Development Review, Vol. 33, pp. 193-203.

Yee Ee, C. (2016), "Export-led growth hypothesis: empirical evidence from selected Sub-Saharan African countries", Procedia Economics and Finance, Vol. 35, pp. 232-240.

Yi, D.J. and Woo, J.H. (2015), "Democracy, policy, and inequality: efforts and consequences in the developing World”, International Political Science Review, Vol. 36 No. 5, pp. 475-492.

\section{Appendix \\ List of Countries}

Angola ${ }^{\text {a, c}}$, Benin, Botswana, Burkina Faso ${ }^{c}$, Burundi, Cameroon ${ }^{c}$, Central African Republic ${ }^{\mathrm{a}}$, Chad $^{\mathrm{c}}$, Comoros, Congo ${ }^{\mathrm{a}, \mathrm{c}}$, Democratic Republic of Congo ${ }^{\mathrm{b}}$, Ethiopia ${ }^{\mathrm{b}, \mathrm{c}}$, Gabon $^{\mathrm{a}, \mathrm{c}}$, Gambia $^{\mathrm{c}}$, Ghana ${ }^{\mathrm{b}}$, Guinea ${ }^{\mathrm{a}, \mathrm{c}}$, Guinea-Bissau, Ivory Coast ${ }^{\mathrm{c}}$, Kenya, Lesotho, Liberia, Madagascar, Malawi, Mali, Mozambique ${ }^{\mathrm{a}, \mathrm{b}}$, Namibia, Niger ${ }^{\mathrm{a}}$, Nigeria ${ }^{\mathrm{b}}$, Rwanda ${ }^{\mathrm{a}, \mathrm{c}}$, Senegal, Sierra Leone ${ }^{\mathrm{a}}$, South Africa ${ }^{\mathrm{b}}$, Swaziland ${ }^{\mathrm{c}}$, Tanzania ${ }^{\mathrm{c}}$, Togo ${ }^{c}$, Uganda ${ }^{c}, Z^{2}$ ambia $^{a}, Z_{\text {Zimbabwe }}{ }^{c}$

a represents resource-export dependent countries. ${ }^{\mathrm{b}}$ represents countries where the average of net FDI inflows exceeds $5 \%$ of total inflows. ${ }^{c}$ represents countries where the average normalized Polity V score is below 0.5 .

\section{Corresponding author}

Sean Gossel can be contacted at: gosselse@gsb.uct.ac.za
FDI and inequality in Sub-Saharan Africa 